\title{
PPM KELOMPOK GURU PENGEMBANG KREASI KAIN MOTIF SHIBORI DENGAN PEWARNA ALAMI DI SD AL KAUTSAR PAKAL SURABAYA
}

\author{
Dwi Hardaningtyas ${ }^{1}$, Arini Sulistyowati ${ }^{2}$, Nur Rahmawati ${ }^{3}$, Elisa Vina Ivanka ${ }^{4}$ \\ ${ }^{1}$ Universitas Wijaya Putra \\ ${ }^{2}$ Universitas Wijaya Putra \\ ${ }^{3}$ Universitas Wijaya Putra \\ ${ }^{4}$ Universitas Wijaya Putra
}

dwihardaningtyas@uwp.ac.id, arinisulistyowati@uwp.ac.id, nurrachma2206@gmail.com, elisaivanka@gmail.com

\begin{abstract}
Abstrak
Pendidikan Lingkungan Hidup (PLH) sudah mulai diterapkan dalam dunia pendidikan di Indonesia. Banyak sekolah sudah mulai melakukan upaya meningkatkan perilaku kepedulian terhadap lingkungan dalam kegiatan pembelajarannya. SD Al Kautsar Surabaya merupakan salah satu sekolah yang pembelajarannya menerapkan pendidikan lingkungan Hidup. Dalam pelajaran Seni Budaya Keterampilan kelas 6, siswa sering diajak untuk membuat karya kain ikat celup/jumputan, namun masih menggunakan pewarna sintetis yang cenderung mencemari lingkungan. Kegiatan PPM ini diharapkan menjadi solusi bagi SD Al Kautsar, karena dalam kegiatan ini guru diberi pelatihan membuat pewarna alami dari bahan yang mudah didapat di lingkungan sekolah. Selain itu untuk mengembangkan desain ikat celup/jumputan, guru juga diberi pelatihan tentang pembuatan kain motif arashi dan itajime shibori. Pembuatan kain motif shibori merupakan teknik ikat celup juga. Teknik ikat celup ini cenderung lebih sederhana dan lebih mudah pengerjaannya dibandingkan dengan membuat batik, sehingga dipilih sebagai kegiatan yang sesuai untuk perkembangan motorik (keterampilan) siswa kelas 6. Selanjutnya guru melakukan diseminasi pada siswa kelas 6. Diseminasi ini meliputi pembelajaran membuat pewarna alami dari daun mangga, pembelajaran membuat kain ikat celup motif arashi dan itajime shibori serta membuat karya kreatif yang bermanfaat dan dibutuhkan berbahan kain shibori pewarna alami dengan harga jual yang terjangkau, seperti konektor masker, karet rambut, maupun taplak meja.
\end{abstract}

Kata Kunci : pewarna alami, arashi shibori, itajime shibori, diseminasi, karya kreatif

\section{PENDAHULUAN}

Pendidikan lingkungan hidup sangat penting ditanamkan sejak dini agar anak terbiasa mencintai lingkungan dan tidak melakukan hal-hal yang merusak lingkungan. Pemerintah Indonesia melakukan upaya meningkatkan perilaku kepedulian lingkungan dalam dunia pendidikan dengan mengadakan Pendidikan Lingkungan Hidup (PLH). SD Al Kautsar Surabaya adalah sekolah yang pembelajarannya menerapkan PLH. Seluruh kegiatan yang ada di sekolah harus memasukkan unsur-unsur kepedulian terhadap lingkungan. Dalam pembelajaran Seni Budaya Ketrampilan di kelas 6, 
para siswa diberi kegiatan membuat kain ikat celup. Ikat celup merupakan salah satu kearifan lokal yang patut dikenalkan pada siswa, kemudian bisa dikembangkan lebih lanjut dalam bentuk produk unggulan.

Berbagai teknik ikat celup yang sudah pernah dipelajari sebelumnya di SD Al Kautsar adalah teknik jumputan (meliputi teknik ikat dan teknik jahit) dan teknik GULIJAT (meliputi teknik gulung, lipat, jahit dan ikat). Teknik-teknik ini termasuk cukup mudah dilakukan, namun membutuhkan ketelatenan. Dengan cara membungkus kelereng dengan kain kemudian mengikatnya atau dengan cara melipat-lipat kain, setelah itu mencelupkannya pada pewarna yang sudah disiapkan. Beberapa jam kemudian kain dibilas air dan dikeringkan. Dengan teknik tersebut sudah bisa menghasilkan motif kain yang cukup bagus. Namun sayangnya kegiatan ini masih menggunakan pewarna sintetis yang tidak ramah terhadap lingkungan. Limbahnya bisa mencemari lingkungan. Oleh karena itu dibutuhkan terobosan baru dalam mengatasi permasalahan ini.

Di sisi yang lain, salah satu perwujudan perilaku ramah lingkungan di SD Al Kautsar adalah pemeliharaan pohon dan tanaman, Pohon-pohon mangga yang banyak tumbuh di halaman sekolah secara berkala dipangkas daunnya agar tidak terlalu rimbun. Hasil pangkasan daun-daun tersebut biasanya hanya diolah sebagai kompos. Kuantitas sampah daun yang melimpah, kadang tidak tertampung secara keseluruhan di bak komposter yang ada. Hal ini memunculkan ide pembuatan pewarna alami dari sampah daun tersebut. Pewarna alami tersebut nantinya akan dipergunakan sebagai pewarna kain dalam pembuatan kain ikat celup. Kegiatan ini merupakan bagian dari inovasi dalam PRLH (Perilaku Ramah Lingkungan Hidup).

Tujuan kegiatan PPM ini adalah membantu mitra dalam mengatasi permasalahannya, dengan cara memberi pelatihan pembuatan kain bermotif shibori dengan pewarna alami yang diproduksi sendiri. Motif shibori ini dipilih sebagai pengembangan motif yang sudah pernah dipraktekkan (jumputan dan gulijat). Dengan demikian, kegiatan ini menjadi solusi dalam mengatasi permasalahan mitra, yaitu : 1) meningkatkan pengetahuan/wawasan dan keterampilan guru dan siswa dalam membuat pewarna alami; 2) meningkatkan kemampuan guru dalam menuangkan ide membuat desain kain ikat celup bermotif shibori dengan pewarna alami; 3) meningkatkan ide kreatif guru dalam melakukan diseminasi (transfer of learning, transfer of spirit) pada siswa, 4) meningkatkan keterampilan membuat kerajinan-kerajinan yang memiliki nilai jual.

Pelatihan dan pendampingan merupakan kegiatan yang paling umum dilakukan dalam kegiatan pengabdian masyarakat. Menurut Marzuki (2010:174), pelatihan diartikan sebagai proses pengajaran atau pemberian pengalaman kepada seseorang untuk memperoleh pengetahuan, skill, dan sikap untuk memperoleh sesuatu yang diinginkan. Sedangkan Kamil (2010:153) berpendapat bahwa tujuan pelatihan adalah guna mengembangkan sikap, pengetahuan dan keterampilan, sehingga mampu meningkatkan kesiapan untuk bekerja dan bekerjasama, serta mampu menjadi masyarakat yang lebih inovatif dan kreatif. Adapun mamfaat pelatihan bagi peserta pelatihan menurut Ismail (2010:137) adalah 1) mengembangkan pengetahuan dan keterampilan; 2) menumbuhkan rasa percaya diri; dan 3) meningkatkan kepuasan dalam pengerjaan (Diba, 2021:131)

Zat pewarna alami (ZPA) dalam teknik pewarnaan tekstil merupakan salah satu solusi untuk mengurangi pencemaran lingkungan. Indonesia adalah negara yang memiliki sumber daya alam melimpah. Berbagai macam tanaman yang berpotensi sebagai pewarna alam cukup banyak ditemukan. Keanekaragaman tanaman ini merupakan nilai tambah bagi pengembangan alternative pengganti zat warna berbahan sintetis. Sumber utama bahan pewarna alam ini banyak terkandung pada tumbuh-tumbuhan, yaitu pada daun, batang, kulit, bunga, buah, kulit akar, kulit buah dan bagian lainnya (Manurung, 2012 : 184)

Zat warna alam umumnya didapatkan dari proses ekstrasi dengan cara direbus hingga cairan berubah menjadi zat warna. Pada proses penggunaan zat warna alam dibutuhkan zat pendukung lainnya, kemudian diperlukan proses fiksasi agar memperoleh zat warna alam dengan ketahanan luntur yang baik. Menurut Amalia dan 
Iqbal, fiksasi merupakan proses pencelupan yang bertujuan untuk mengunci warna yang masuk dalam serat kain agar warna yang dihasilkan tidak mudah pudar atau luntur. Menurut Jalaludin, ada 3 jenis fiksator yang sering digunakan, yakni tunjung, tawas, kapur. Dalam proses fiksasi juga dapat menentukan arah hasil jadi warna sesuai dengan fiksator yang digunakan. Proses lain yang menentukan dalam pewarnaan menggunakan pewarna alami adalah proses mordanting. Mordanting bertujuan untuk menghilangkan sisa lemak, minyak, kanji, dan kotoran yang tertinggal pada kain saat proses penenunan sehingga zat warna mampu terserap dengan baik oleh kain. Di sisi yang lain Yonanda (2019 : 34) mengatakan proses mordanting juga dapat digunakan untuk meratakan hasil dan ketajaman warna yang baik ((Diba, 2021 : 130),

Shibori sudah ada sejak jaman kekaisaran Jepang beberapa ratus tahun yang lalu. Shibori berasal dari kata kerja 'shiboru' yakni merupakan teknik pewarnaan kain yang mengandalkan ikatan dan celupan. Dengan teknik ini, beberapa kain "dilindungi" agar tidak terkena corak pewarna sehingga pada hasil akhirnya tercipta pola sesuai dengan bagian yang diwarnai dan "dilindungi". Teknik "melindungi" kain ini bisa dilakukan dengan cara melipat, melilit, mengikat kain dan mencelupkannya pada pewarna. Teknik Arashi Shibori dapat menampilkan motif-motif seperti arus laut, tulang daun, ranting pohon, tanah dan sebagainya (Kautsar, 2017).

\section{METODE}

Untuk membantu mengatasi permasalahan mitra maka dilakukan tahapan atau langkah-langkah sebagai berikut : 1) Pelatihan; 2) Diseminasi Pembelajaran Kreativitas pada siswa; 3)Pendampingan

Pelatihan dalam kegiatan ini ada 2 yaitu pelatihan pembuatan pewarna alami dan pelatihan membuat kain ikat celup motif shibori dengan pewarna alami.

Pada kegiatan pelatihan pembuatan pewarna alami dipilih daun mangga yang banyak dihasilkan dari kegiatan peremajaan pohon di sekolah. Daun-daun tersebut dikumpulkan dan dipilah menjadi 2, daun yang sudah tua dan daun yang masih muda. Tujuan pemilahan daun tersebut adalah ingin mengetahui apakah nanti akan ada perbedaan warna pada saat diaplikasikan pada kain. Adapun proses pembuatannya adalah daundaun tersebut dipotong-potong terlebih dahulu, kemudian diblender. Perbandingan antara air dan daun mangganya adalah 3 lt air : $3 \mathrm{~kg}$ daun mangga.

Setelah itu air yang bercampur daun mangga yang sudah lebih halus direbus sampai mendidih. Setelah rebusan air daun mangga tersebut dingin baru disaring. Selanjutnya, pewarna alami dari bahan daun mangga siap diaplikasikan pada kain.

Sambil menunggu zat pewarnanya dingin, peserta mempersiapkan desain kain yang akan dicelup dengan teknik shibori. Teknik shibori yang diberikan dalam pelatihan ini adalah arashi shibori (dengan cara menggulung kain pada pipa paralon, diikat dan diserut) dan itajime shibori (dengan cara membuat lipatan yang rapi dalam bentuk segiempat atau segitiga kecil dan diberi ikatan). Teknik Arashi Shibori dapat menampilkan motif-motif seperti arus laut, tulang daun, ranting pohon, sedangkan teknik Itajime Shibori menampilkan motif kotak atau segitiga. Pada masing-masing peserta diberikan kain berukuran $1.10 \mathrm{~m} \mathrm{X} 1.10 \mathrm{~m}$, benang besar, karet, serta disiapkan paralon sepanjang $75 \mathrm{~cm}$ bagi peserta yang akan membuat desain dengan teknik arashi shibori.

Sebelum mencelup kain-kain yang sudah digulung dan diserut di paralon, atau yang dilipat kotak-kotak kecil dalam pewarna alami, kaintersebut harus dimordanting terlebih dahulu dengan Ash soda. Mordanting ini bertujuan untuk mempersiapkan kain agar pewarna alam dapat terserap dengan baik. Untuk pembuatan larutan mordanting ini dipergunakan 60 gram ash soda dan 3 liter air. Cara pembuatannya air didihkan terlebih dahulu, kemudian diberi ash soda. Setelah suhunya hangat kain bisa dicelupkan dalam larutan tersebut, kemudian diangin-anginkan hingga kering. Setelah kain tersebut kering, kain siap dicelup pada pewarna alami daun mangga yang sudah disiapkan.

Pada saat pencelupan kain dalam zat pewarna 
alami daun mangga, diupayakan semua bagian dari kain terkena pewarna secara merata. Setelah itu kain tersebut, ditiriskan kemudian dijemur/dianginanginkan. Proses pencelupan ini dilakukan minimal 3-4 kali dalam 24 jam. Kalau menginginkan warna yang lebih tajam proses ini bisa dilakukan $3 \times 24$ jam (3 hari).

Proses selanjutnya adalah melakukan fiksasi untuk mengunci warna yang masuk dalam serat kain agar warna yang dihasilkan tidak mudah pudar atau luntur. Untuk proses fiksasi ini digunakan tunjung. Cara membuatnya adalah dengan mencampurkan 40 gr tunjung pada air 3 liter, aduk rata. Pembuatan larutan tunjung ini sebaiknya dilakukan minimal 12 jam sebelum dipakai untuk memfiksasi kain. Pada saat melakukan fiksasi ini gulungan maupun ikatan pada kain dilepas terlebih dahulu. Setelah kain sudah terkena cairan tunjung selama 3-5 menit, kemudian dilakukan pembilasan dengan air bersih hingga kurang lebih 3 kali. Setelah itu kain dikeringkan.

Kegiatan selanjutnya adalah diseminasi pembelajaran kreativitas pada siswa. Diseminasi disini berarti proses sosialisasi hasil pelatihan pembuatan pewarna alami berbahan daun mangga dan pembuatan kain ikat celup motif shibori dengan pewarna alami. Tidak sekedar melakukan sosialisasi, diseminasi ini bertujuan agar terjadi transfer of learning, transfer of spirit) perilaku ramah lingkungan hidup dari guru kepada siswa. Dalam kegiatan diseminasi ini guru yang mengambil peran sebagai tutor pelatihan. Oleh karena itu tim pengabdian masyarakat tetap memberikan pendampingan terutama dalam menyusun materi pelatihan yang akan disampaikan kepada siswa. Siswa yang dipilih untuk mengikuti kegiatan ini adalah siswa kelas 6. Dari kegiatan tersebut diharapkan siswa mampu meningkatkan ketrampilan membuat kerajinan-kerajinan yang memiliki nilai jual tinggi dan ramah lingkungan.

\section{HASIL DAN PEMBAHASAN}

\section{Pelatihan pembuatan pewarna alami}

Pewarnaan tekstil dengan pewarnaan alami sedikit berbeda dengan pewarnaan tekstil dengan pewarnaan sintetis. Pada pewarnaan tekstil dengan bahan alami perlu membuat pewarnanya terlebih dahulu. Selain itu terdapat proses mordanting dan fiksasi untuk memaksimalkan kualitas pewarnaan pada bahan kain. Namun dengan pewarna alami keuntungannya adalah mengurangi terjadinya pencemaran lingkungan. Pelatihan pembuatan pewarna alami dari daun mangga dapat dilihat dalam gambar berikut ini :

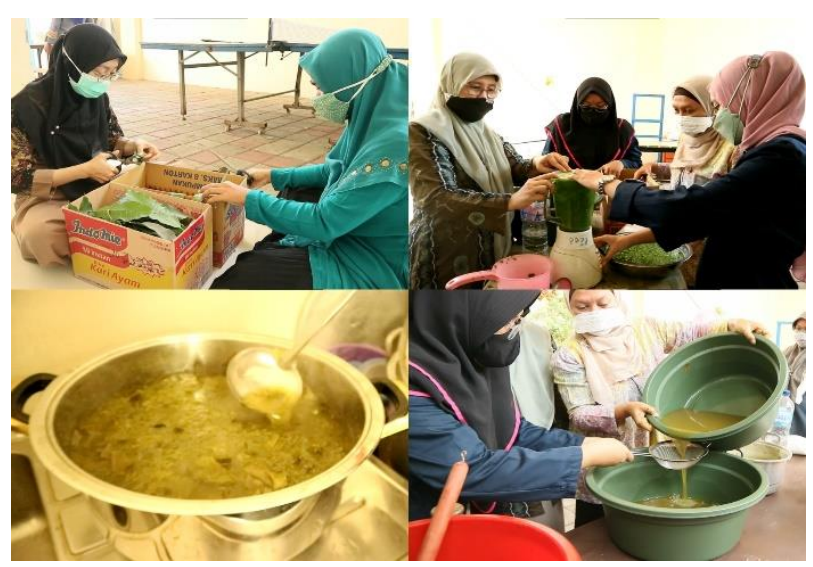

Gambar 1 Pelatihan Pembuatan Pewarna Alami

Dalam pelatihan pembuatan pewarna daun mangga ini diketahui bahwa daun yang sudah tua cenderung memberi warna yang lebih tua, coklat tua kehijauan, sedangkan daun yang masih muda cenderung memberi warna yang lebih muda, mendekati hijau pupus.

\section{Pelatihan pembuatan kain ikat celup motif shibori (arashi shibori atau itajime shibori)}

Motif arashi shibori atau itajime shibori merupakan pengembangan dari kegiatan membuat ikat celup di SD Al Kautsar. Motif ini sedikit berbeda dari jumputan yang sudah sering diberikan pada pembelajaran SBK di kelas 6. Motif arashi shibori membutuhkan bantuan pipa paralon (atau benda lain yang berbentuk tabung) untuk menempatkan kain yang akan diikat dan diserut.

Kegiatan pelatihan motif shibori ini dapat dilihat pada gambar berikut ini : 


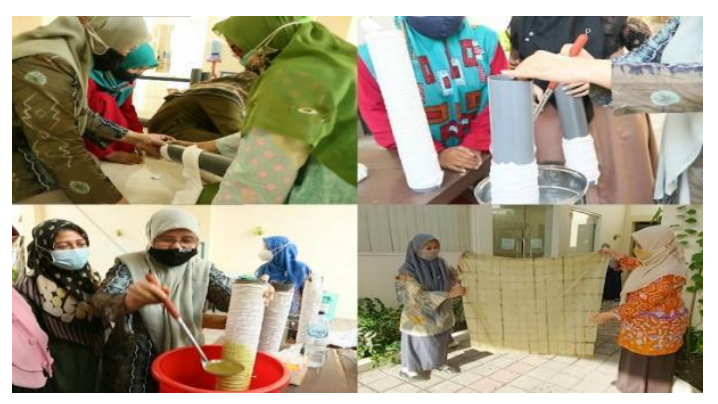

Gambar 2 Pelatihan Pembuatan Motif Shibori

Hasil pewarnaan yang diperoleh dari pewarna daun mangga yang masih muda ketika diaplikasikan pada kain dan dilakukan fiksasi dengan tunjung, ternyata menghasilkan warna yang lebih muda. Di sisi yang lain, hasil pewarnaan yang diperoleh dari pewarna daun mangga yang tua ketika diaplikasikan pada kain dan dilakukan fiksasi dengan tunjung, ternyata menghasilkan warna yang lebih tua/gelap. Hal ini bisa dilihat pada gambar berikut ini :

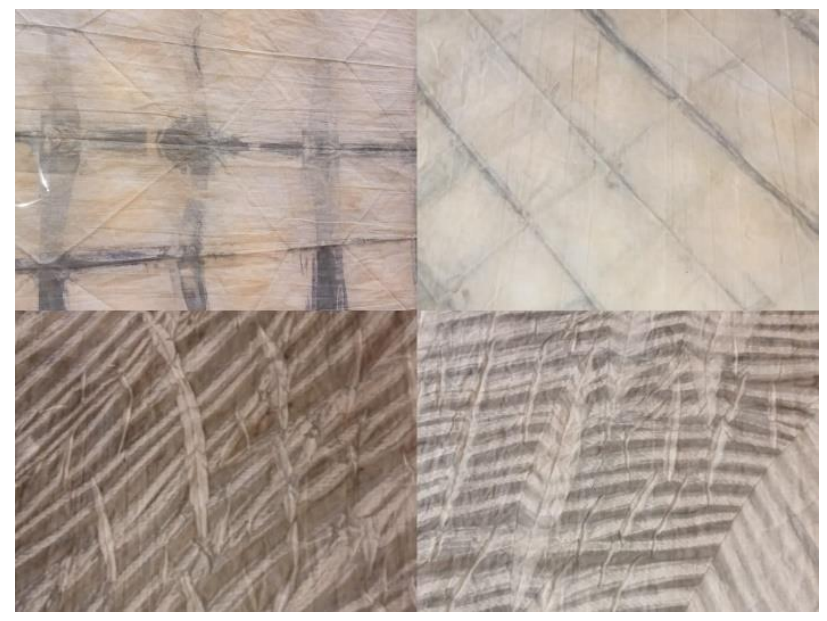

Gambar 3 Kain Motif Shibori dengan Pewarna Daun Mangga

Motif arashi shibori terlihat sangat alami, berbentuk seperti serat kayu. Dalam pewarnaan kain dengan motif ini dihasilkan gradasi warna yang semakin muda pada gulungan kain bagian dalam. Oleh karena itu pengaplikasian teknik ini akan lebih baik hasilnya apabila kain dilipat segitiga (secara diagonal) terlebih dahulu baru kemudian diikat dan diserut dengan tali. Cara menggulungnya pun dimulai dari sisi yang

lebar terlebih dahulu hingga pada ujung segitiga.

Dalam pelatihan ini, motif arashi shibori ini merupakan motif yang sangat disukai guru-guru. Hal ini memotivasi guruguru untuk memproduksi kain ikat celup motif arashi shibori.

\section{Diseminasi pembelajaran kreativitas pada siswa}

Kegiatan pengabdian masyarakat di SD Al Kautsar ini bertujuan untuk meningkatkan keterampilan guru maupun siswa dalam hal membuat pewarna alami yang diproduksi sendiri, dan membuat kain bermotif shibori. Tim pengabdian masyarakat memberikan pendampingan pada guru agar dapat melakukan diseminasi pembelajaran kreativitas ini pada siswa. Dengan memanfaatkan channel youtube, guru diajak melihat video kreativitas pembuatan kain shibori serta pembuatan berbagai asesoris dari bahan kain. Selanjutnya antara tim pengabdian masyarakat dan guru menentukan bersama kegiatan diseminasi untuk siswa.

Diseminasi pada siswa meliputi kegiatan pembuatan pewarna alami, pembuatan kain motif shibori, pembuatan hasil karya dari kain shibori yang sudah diproduksi sendiri. Kerajinan/kriya yang diberikan pada siswa kelas 6 adalah pembuatan taplak meja, konektor masker, dan juga karet rambut. Pembuatan konektor masker dan karet rambut dipadukan dengan keterampilan menjahit tanpa menggunakan mesin jahit.

Kegiatan ini diharapkan dapat memberi spirit dan wawasan cinta lingkungan dengan menggunakan pewarna alami yang ramah lingkungan. Pembuatan warna alami merupakan sebuah inovasi dalam perilaku ramah lingkungan. Guru harus mampu mengajarkan hasil pelatihan dalam kegiatan PPM ini kepada siswanya. Berikut ini merupakan kegiatan diseminasi di SD Al 
Kautsar.

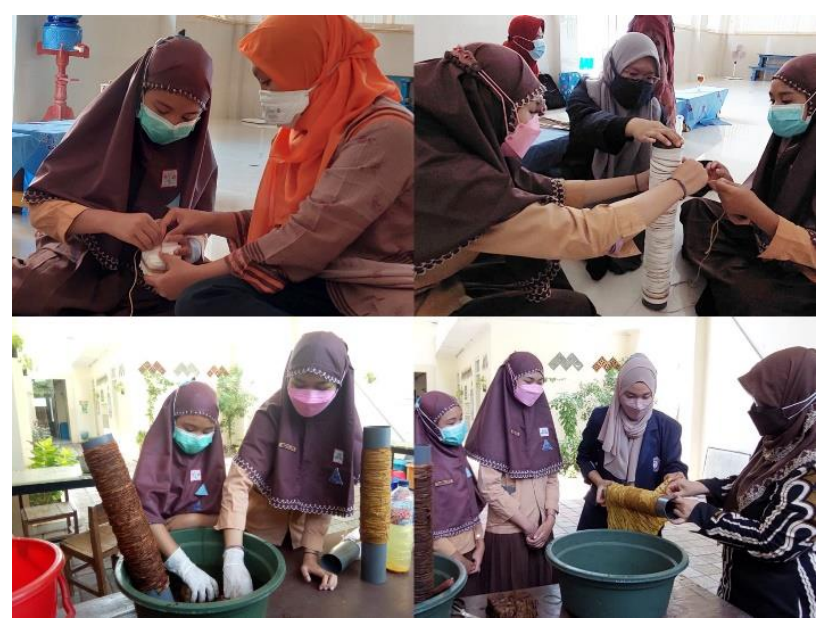

Gambar 3 Diseminasi Pembelajaran Kreativitas pada Siswa

\section{KESIMPULAN}

Hasil yang diperoleh dalam kegiatan ini adalah 1) peningkatan pengetahuan/wawasan dan keterampilan guru dan siswa kelas 6 dalam membuat pewarna alami, dengan membuat pewarna alami sendiri memunculkan rasa puas karena bisa memanfaatkan daun-daun yang ada di lingkungan sekitar 2) peningkatan kemampuan guru dalam menuangkan ide membuat desain kain ikat celup bermotif shibori (arashi shibori dan itajime shibori) dengan pewarna alami, hal ini dapat dilihat dari hasil pewarnaan kain yang dibuat guru maupun siswa kelas 6 cukup kreatif; 3) peningkatan ide kreatif guru dalam melakukan diseminasi (transfer of learning, transfer of spirit) pada siswa, yang diwujudkan dalam pembelajaran SBK khususnya di kelas 6 ; 4) peningkatkan keterampilan membuat kerajinan-kerajinan yang memiliki nilai jual seperti taplak meja, konektor masker, dan karet rambut.

\section{UCAPAN TERIMAKASIH}

Pada kesempatan ini, tim pengabdian masyarakat mengucapkan terima kasih yang sebesar-besarnya kepada Lembaga Penelitian dan
Pengabdian pada Masyarakat (LPPM) Universitas Wijaya Putra Surabaya yang telah memberikan kontribusi dalam pelaksanaan kegiatan.

\section{REFERENSI}

Diba, Farah. (2021). Wahyuningsih, Urip. Studi Literatur : Pelatihan Ikat Celup sebagai Upaya Pemberdayaan terhadap penggunaan pewarna alam. e-journal, 10(1), Edisi Yudisium

Kusumayanti, Heny., dkk, 2020., Pelatihan pembuatan batik Shibori bagi pengurus daerah Wanita Islam Kota Semarang., Jurnal Pengabdian Vokasi Volume 01 No 3, ISSN 2621-8801

Ristamadi, Florentina Irena, dkk., 2019., Pengembangan batik dan kreasi batik sebagai ekstra kurikuler unggulan SD Kuncup Melati Semarang., Jurnal Patria Vol 1 No 1, ISSN : 26565455 (media online)

Dinda Siti Kautsar. (2017). Eksplorasi Teknik Shibori Pada Pakaian Ready to Wear. eProceeding of Art \& Design, 4(3) : 23559349

Manuntun Manurung. (2012). Aplikasi Kulit Buah Manggis (Garcinia Mangostana L) sebagai Pewarna Alami Pada Kain Katun Secara Pre Mordanting. Jurnal Kimia 6 (2): 1907-9850

Fitria Hanida Indriani. 2020. Kebijakan Gerakan Peduli Dan Berbudaya Lingkungan Hidup Di Sekolah (Pblhs) (Bagian 1)

https://dlh.banjarmasinkota.go.id/2020/0 6/kebijakan-gerakan-peduli-danberbudaya.html (diakses pada tanggal 23 Maret 2021 jam $10.31 \mathrm{wib})$

Woman. 24 Septembr 2018. Bagi pegiat kesenian dan tekstil, istilah shibori bukanlah hal yang asing ditelinga. https://kumparan.com/kumparanstyle/ber kenalan-dengan-shibori-si-kain-batik- 
asal-jepang-1537789140189718307/full (diakses pada tanggal 23 Maret 2021 jam $10.17 \mathrm{wib})$

Ilham Wahyu Hidayat. 07 April 2020. Gerakan

Peduli dan Berbudaya Lingkungan Hidup

Sekolah

https://lenteratoday.com/gerakan-peduli-

dan-berbudaya-lingkungan-hidup-

sekolah/ 